\title{
Study of histomorphological spectrum of eyelid lesions
}

\author{
Reshmi Shrestha ${ }^{1}$, Gita Sayami \\ ${ }^{I}$ Department of Pathology, Nepalese Army Institute of Health Sciences, Kathmandu, Nepal \\ ${ }^{2}$ Department of Pathology; Hospital for Advanced Medicine and Surgery, Kathmandu, Nepal
}

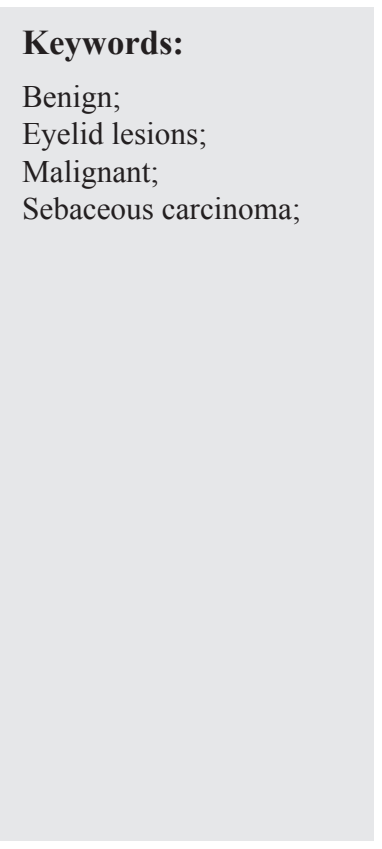

\begin{abstract}
Background: Eyelid pathologies are the most common surgical specimens encountered among all of the ophthalmic lesions and constitute a wide range of diseases by their unique histologic features. This study aims to find out the histopathological spectrum of eyelid lesions, their demographic distribution, and preferential location prevalent in our community.
\end{abstract}

Materials and Methods: This is an observational study in which we retrospectively evaluated the data of 692 patients retrieved from the histopathology department of National Reference Laboratory, Kathmandu, from May 2016 to April 2019.

Results: A total of 701 histologic diagnoses comprised of benign, precursor, and malignant lesions and accounted for $86.6 \%, 2.6 \%$, and $10.8 \%$ respectively with preponderance in females. The common benign lesions included melanocytic nevus (17.7\%), epidermal cyst (11\%), hemangioma (8.9\%), dermoid cyst $(8.2 \%)$, chalazion $(6.7 \%)$, and squamous papilloma (6.4\%). Tumour of epidermal origin was the most common neoplastic lesion accounting for $31.2 \%$. Basal cell carcinoma (50\%) followed by sebaceous carcinoma (27.6\%) and squamous cell carcinoma (14.5\%) constituted the majority of malignant lesions prevalent above the age of 60 years with the preferential site of the upper eyelid for basal cell carcinoma and squamous cell carcinoma; and lower eyelid for sebaceous carcinoma.

Conclusions: Benign eyelid lesions are more prevalent than malignant ones with overall female preponderance. Epidermal tumours are common among neoplasms. A malignant tumour, a disease of an elderly individual, is predominated by basal cell carcinoma followed by sebaceous carcinoma, an aggressive tumour with a high recurrence rate in our population.

\section{Correspondence:}

Dr. Reshmi Shrestha, MD

Associate professor, Department of Pathology

Nepalese Army Institute of Health Sciences

ORCID ID: 0000-0002-9914-9213

Email: reshmishrestha2070@gmail.com

Received : $23^{\text {rd }}$ December 2020 ; Accepted : March $7^{\text {th }} 2020$

Citation: Shrestha R, Sayami G. Study of histomorphological spectrum of eyelid lesions. J Pathol Nep. 2021;11:1790-1802 DOI: 10.3126/jpn.v11i1.31244

Copyright: This is an open-access article distributed under the terms of the Creative Commons Attribution 4.0 International License, which permits unrestricted use, distribution, and reproduction in any medium, provided the original author and source are credited.

\section{INTRODUCTION}

Eyelid lesions are quite common and most of the surgically excised ophthalmic specimens submitted for histopathologic evaluation are obtained from this site. Numerous and diverse pathologic lesions in the eyelids are due to their unique anatomical features as the whole skin structures with its appendages, skeletal muscle, modified glands, and conjunctival mucous membrane are represented in the eyelid. ${ }^{1,2}$ Eyelid lesions can be divided into congenital, inflammatory, nonneoplastic masses, and neoplasms (benign or malignant). Neoplastic lesions can be further classified 
according to their anatomical origin. ${ }^{2-4}$

The relative frequencies of different eyelid lesions are variable from different locations in the world as reported in the literature. ${ }^{5}$ Benign lesions are more common than malignant lesions. ${ }^{6,7}$ Basal cell carcinoma has been shown to have the highest incidence among malignancies in the West but a higher incidence of sebaceous carcinoma is documented in Asian countries..$^{711}$ Geographic variation, genetic factors, socioeconomic status, easy access to health care facilities has been attributed to the variations seen in the frequency of various tumour subtypes in different studies. ${ }^{11}$

Malignant eyelid lesions may masquerade as both benign and histologically different types of malignant lesions, often resulting in delayed diagnosis. ${ }^{6,12}$ Histopathological evaluation is important in early detection, prompt treatment, and further management of malignant tumours. ${ }^{6,13}$

There has been a limited number of studies on eyelid lesions in Nepal which mostly include a very less number of cases. We aimed to evaluate the histomorphological spectrum of eyelid lesions and their frequency and demographic and topographic distribution from the data of 692 patients at the Kathmandu-based referral laboratory.

\section{MATERIALS AND METHODS}

This was a retrospective observational study conducted during the period of three years from May 2016 to April 2019. A total of 692 patients with eyelid lesions were included who submitted their biopsy specimens in the histopathology department of National Reference Laboratory, Baneshwor, Kathmandu for histopathological examination.

This study received the approval of the Institutional Review Committee of the Nepalese Army Institute of Health Sciences. Clinical data, demographic characteristics, location of the lesions, gross features, and histopathologic diagnoses with detailed histologic findings, marginal tissue involvement in malignant lesions were retrieved from the histopathology record database. Haematoxylin and eosinstained slides were also retrieved and reviewed wherever necessary. Eyelid tissue with histologically nonspecific descriptive findings, such as consisting of only normal tissue was excluded. The recurrent tumour was not repeated as a separate case in this study. Laterality of the eyelid lesions was not found in the record in most of the cases, therefore it could not be determined. Statistical analysis of the frequency of eyelid diseases, their demographic and topographic distribution, and clinical characteristics were done by using SPSS 20 software.

Eyelid lesions were grouped into four categories i.e., non-neoplastic lesion, benign tumour, precursor lesion, and malignant tumour. Nonneoplastic lesions and benign tumours were together considered as benign eyelid lesions. Nonneoplastic lesions were further categorized into the inflammatory lesion, cyst/congenital lesion, infectious lesion, and cutaneous deposit., ${ }^{3,14}$

The classification of tumours used in this study is based on the WHO Classification of Skin Tumours (2018) ${ }^{15}$ along with the revised 2006 edition of the AFIP atlas of tumour pathology 1 and Mckee et al ${ }^{16}$.

The retrieved data from the pathology department of this referral laboratory showed that the patients were predominantly from Central (Kathmandu, Lalitpur, Bhaktapur, Makwanpur, Chitwan) and Eastern region (Jhapa) of Nepal. These major cities have a diverse population in terms of race and ethnicity with good health care facilities. The geographic altitude varies and the climate zone ranges from temperate to tropical climate. Literacy rate, socioeconomic status, and disease awareness are also considered better amongst different regions of Nepal based on the National Population and Housing Census 2011, national report. ${ }^{17}$

\section{RESULTS}

A total of 692 patients with eyelid lesions were studied during the period of three years from May 2016 to April 2019, of which 400 (57.8\%) were females and $292(42.2 \%)$ were males with a female to male ratio of 1.3:1.

Total histologic diagnoses were found to be 701 in these 692 patients as some of the patients had more than one diagnosis in the biopsied specimen. Of these 701 diagnoses, benign lesions were the most common eyelid lesions $(n=607$; $86.6 \%)$ which included nonneoplastic lesions $(n=242$; $34.5 \%)$ and benign neoplastic lesions $(n=365 ; 52.1 \%)$ followed by malignant lesions $(n=76 ; 10.8 \%)$ and precursor lesions were found to be $18(2.6 \%)$. Eyelid neoplasms accounted for 459 lesions. Females predominated in benign and malignant tumours with a female to male ratio of 1.6:1 and 1.9:1. Equal distribution was noted in nonneoplastic lesions with a female to male ratio of 1.07:1. In precursor lesions, males predominated (1:1.6).

The mean age of patients with benign eyelid lesions was $33.7 \pm 19.2$ years (median age, 31years) ranging from 1 to 84 years. Among the patients with benign lesions, the average age for nonneoplastic lesions and benign tumours was 28 years and 37.5 years respectively. The mean age of patients with malignant tumour was $60.3 \pm 17.8$ years (median age, 65 years) with ages ranging from 5-97 years. Precursor lesions were seen in the patients with a mean age of $48.2 \pm 20.2$ years (median age, 50.5years) and age ranging from 9-84 years. Preferential locations for the eyelid lesions are presented in Table 1.

Non-neoplastic lesions were predominantly cysts followed by inflammatory lesions in the eyelid (Table 2). Among the non-neoplastic lesions, epidermal cyst was the most common finding $(n=65 ; 26.9 \%)$ followed by dermoid cyst 
Table 1: Topographic distribution of different categories of eyelid lesions

\begin{tabular}{lccccc}
\hline Location & Upper eyelid & Lower eyelid & Medial Canthus & Lateral Canthus $\begin{array}{c}\text { Both upper and } \\
\text { lower eyelids }\end{array}$ \\
\hline Benign Lesions & 352 & 176 & 43 & 26 & 10 \\
\hline Precursor lesions & 11 & 5 & 1 & 1 & 0 \\
\hline Malignant Lesions & 32 & 37 & 3 & 1 & 3 \\
\hline Total & $\mathbf{3 9 5}$ & $\mathbf{2 1 8}$ & $\mathbf{4 7}$ & $\mathbf{2 8}$ & $\mathbf{1 3}$ \\
\hline
\end{tabular}

Table 2: Frequency, demography and topographic distribution of various non-neoplastic lesions, $(\mathrm{n}=\mathbf{2 4 2})$

\begin{tabular}{|c|c|c|c|c|c|c|}
\hline Type of non-neoplastic lesions & No. cases & $\begin{array}{l}\text { All lesions } \\
(\%)\end{array}$ & $\begin{array}{c}\text { Mean age } \\
\text { (range years) }\end{array}$ & $\begin{array}{c}\text { Peak age } \\
\text { interval years }\end{array}$ & $\begin{array}{l}\text { Sex ratio } \\
\text { (F:M) }\end{array}$ & $\begin{array}{c}\text { Location (UL/ } \\
\text { LL) }\end{array}$ \\
\hline \multicolumn{7}{|l|}{ Inflammatory lesions $(\mathrm{n}=82)$} \\
\hline Chalazion & 41 & 5.8 & $24.8(4-70)$ & $21-30$ & $1.4: 1$ & $1.7: 1$ \\
\hline Inflammatory granulation tissue & 28 & 4 & $23.9(2-74)$ & $<-10$ & $1.3: 1$ & $2.7: 1$ \\
\hline Nonspecific chrunic inflammation & 7 & 1 & $39.9(5-71)$ & $>60$ & $1.3: 1$ & $4: 1$ \\
\hline Granulomatous inflammation & 4 & 0.6 & $35.3(22-62)$ & $21-30$ & $3: 1$ & $3: 1$ \\
\hline Pemphigus vulgaris & 1 & 0.1 & 8 & $<=10$ & $1: 0$ & $1: 0$ \\
\hline Panniculitis & 1 & 0.1 & 36 & $31-40$ & $0: 1$ & $1: 0$ \\
\hline \multicolumn{7}{|l|}{ Cyst/Congenital lesions $(n=130)$} \\
\hline Epidermal cyst & 65 & 9.3 & $36.5(2-82)$ & $51-60$ & $1: 1.1$ & $2.7: 1$ \\
\hline Dermoid cyst & 50 & 7.1 & $23.9(1-84)$ & $<=10$ & $1: 1.3$ & $6.1: 1$ \\
\hline Trichilemmal cyst & 2 & 0.3 & $46.5(38-55)$ & $31-40 ; 51-60$ & $1: 1$ & $0: 2$ \\
\hline Choristoma & 13 & 1.9 & $17.5(1-53)$ & $11-20$ & $1.6: 1$ & $1: 1+$ \\
\hline \multicolumn{7}{|l|}{ Infection/Infestation $(n=25)$} \\
\hline Molluscum contagiosum & 22 & 3.1 & $19.6(5-60)$ & $<=10$ & $1: 1$ & $1.7: 1$ \\
\hline Rhinosporidiosis & 1 & 0.1 & 78 & $>60$ & $1: 0$ & $0: 1$ \\
\hline Actinomycosis & 2 & 0.3 & $35(20-50)$ & $11-20$ & $1: 1$ & MC \\
\hline \multicolumn{7}{|l|}{ Cutaneous deposits $(n=5)$} \\
\hline Amyloidosis & 3 & 0.4 & $48.3(23-61)$ & $>60$ & $0: 3$ & $3: 0$ \\
\hline Calcinosis cutis & 2 & 0.3 & $12.5(11-14)$ & $11-20$ & $1: 1$ & $1: 1$ \\
\hline
\end{tabular}

*female/male; †upper eyelid/lower eyelid; ;medial canthus=lateral canthus; §all medial canthus

$(\mathrm{n}=50 ; 20.7 \%)$ and chalazion $(\mathrm{n}=41 ; 17.4 \%)$. Foreign body giant cell reaction was a common finding in the wall of the epidermal cyst $(n=10)$ and dermoid cyst $(n=18)$ with partial denudation of the overlying epithelium. Chalazion was recognized histologically by the presence of granulomatous reaction around fat vacuoles (fig. 1A) and three of these were associated with inflammatory granulation tissue formation while one had overlying epithelium showing reactive changes. Other nonneoplastic lesions included inflammatory granulation tissue $(\mathrm{n}=28)$ which was mostly excised with the clinical diagnoses of foreign body granuloma or pyogenic granuloma. The next frequently occurring lesion was the infectious lesion i.e., molluscum contagiosum, $(n=22)$. Histologically, it showed characteristic eosinophilic molluscum bodies in the lobules of squamous epithelium (fig. 1B). Choristoma ( $\mathrm{n}=13)$, a congenital lesion was more common in adolescents at presentation. Granulomatous lesions included foreign body granulomas $(\mathrm{n}=2)$, sarcoidosis $(\mathrm{n}=1)$ and tuberculosis $(\mathrm{n}=1)$. Other less common non-neoplastic lesions which were less than $1 \%$, included amyloidosis, calcinosis cutis, trichilemmal cysts, actinomycosis, rhinosporidiosis, Pemphigus Vulgaris, and panniculitis.
Tables 3, 4, and 5 show the frequency of histological subtypes, the age and sex ratio of patients, and preferential site of the tumour of the epidermal origin, appendageal tumour, and other tumour types (melanocytic tumour, soft tissue tumour, lymphoid tumour, and histiocytic lesions) respectively. Tumours of the epidermal origin were the commonest neoplasm in the eyelid $(n=143,31.2 \%)$ followed by tumours of melanocytic origin ( $\mathrm{n}=110,23.9 \%)$, appendageal tumours $(\mathrm{n}=100,21.8 \%)$ and soft tissue tumours ( $\mathrm{n}=91,19.8 \%$ ). However, amongst the benign tumours, melanocytic nevus outnumbered other benign tumours ( $\mathrm{n}=108,29.6 \%$ of all benign tumours). The second most common benign neoplasm was haemangioma $(\mathrm{n}=$ $54,14.8 \%$ ). Whereas squamous papillomas, the tumour of epidermal origin, was the third most common benign tumour $(n=39 ; 10.7 \%)$ followed by hydrocystoma $(n=36$; $9.9 \%)$ and seborrheic keratosis $(\mathrm{n}=31 ; 8.5 \%)$.

Squamous papilloma, the commonest benign epidermal tumour, showed typical papillary lesions with fibrovascular core and one of them had heavily mixed inflammatory infiltrate in the underlying dermis probably consistent with infected papilloma. One case of squamous papilloma 


\begin{tabular}{|c|c|c|c|c|c|c|c|}
\hline Type of non-neoplastic lesions & $\begin{array}{l}\text { No. } \\
\text { cases }\end{array}$ & $\begin{array}{l}\text { All Tumors } \\
(\%)\end{array}$ & $\begin{array}{l}\text { All lesions } \\
(\%)\end{array}$ & $\begin{array}{c}\text { Mean age } \\
\text { (range years) }\end{array}$ & $\begin{array}{c}\text { Peak age } \\
\text { interval years }\end{array}$ & $\begin{array}{c}\text { Sex ratio } \\
\text { (F:M) }\end{array}$ & $\begin{array}{l}\text { Location } \\
\text { (UL/LL) }\end{array}$ \\
\hline \multicolumn{8}{|l|}{ Benign epidermal tumour $(n=76)$} \\
\hline Squamous papilloma & 39 & 8.5 & 5.5 & $36(8-75)$ & $31-40$ & $2: 1$ & $1.1: 1$ \\
\hline Seborrheic keratosis & 31 & 6.7 & 4.4 & $41.8(11-84)$ & $31-40$ & $2.1: 1$ & $1.2: 1$ \\
\hline Lichenoid keratosis & 1 & 0.2 & 0.1 & 65 & $>60$ & $1: 0$ & $0: 1$ \\
\hline Verrucae vulgaris & 5 & 1.1 & 0.7 & $42.2(20-75)$ & $21-30 ;>60$ & $4: 1$ & $4: 1$ \\
\hline \multicolumn{8}{|l|}{ Precursor lesions $(n=18)$} \\
\hline Actinic keratosis & 10 & 2.2 & 1.4 & $45.7(9-84)$ & $41-50$ & $1: 1.5$ & $4: 1$ \\
\hline SCC in situ & 6 & 1.3 & 0.9 & $53.2(27-74)$ & $>50$ & $1: 1$ & $1: 1$ \\
\hline S. papilloma with dysplasia§ & 1 & 0.2 & 0.1 & 35 & $31-40$ & $0: 1$ & $\mathrm{LC}$ \\
\hline S. keratosis with dysplasia & 1 & 0.2 & 0.1 & 58 & $51-60$ & $0: 1$ & $0: 1$ \\
\hline \multicolumn{8}{|c|}{ Malignant epidermal tumour $(n=49)$} \\
\hline $\mathrm{BCC}$ & 38 & 8.3 & 5.4 & $66.1(25-97)$ & $>60$ & $1.7: 1$ & $0.4: 1$ \\
\hline SCC & 11 & 2.4 & 1.6 & $48.7(27-74)$ & $>60$ & $2.7: 1$ & $0.6: 1$ \\
\hline
\end{tabular}

*female:male; †upper eyelid/lower eyelid; łsquamous cell carcinoma in situ; §squamous papilloma with dysplasia; ||lower canthus; $\mid$ |seborrheic keratosis with dysplasia; **basal cell carcinoma; †'squamous cell carcinoma

developed dysplasia and thus was categorized underprecursor lesion. Another common epidermal tumour, i.e., seborrheic keratosis, was composed of acanthotic papillomatous lesion lined by basaloid keratinocytes along with multiple pseudo-horn cysts formation. Keratotic, pigmented, and irritated (inverted follicular keratosis) variants were also seen showing histologic features of marked hyperkeratosis, increased keratinocytes pigmentation with scattered melanophages, and presence of squamatization, squamous eddies with a band of superficial lymphocyte infiltrate in the dermis respectively. One case of seborrheic keratosis was also found to be associated with dysplasia, which was, therefore, considered a precursor lesion.

Among the appendageal neoplasms, tumours with eccrine and apocrine differentiation were the most frequent ones accounting for $10 \%(n=46)$ of all tumours. Hidrocystoma was the most common type of benign adnexal tumour and was predominantly of eccrine type. Only one case of apocrine hydrocystoma was detected consisting of a cyst lined by apocrine cells. Secondly, pilomatrixoma, an adnexal tumour with follicular differentiation was seen with a frequency of $3.8 \%(n=14)$ of all benign tumours. The frequency of other less common adnexal tumours is provided in Table 4.

The commonest melanocytic nevus which is intradermal type accounted for $26.3 \%$ ( $\mathrm{n}=96)$ of all benign tumours and histologically, dermal nests of nevus cells showing maturation were conspicuously present. Some of the intradermal nevi also showed multinucleated giant cells in the dermis which has, however, no significance (fig. 1C). Compound nevus was less frequently seen in comparison to intradermal nevus occurring with a frequency of 3.3\% $(n=12)$ of benign tumours. One compound nevus was clinically diagnosed as kissing nevus involving both upper and lower eyelids. No single junctional nevus or other specific variants of melanocytic nevus was found in the eyelid.

Frequently seen hemangioma was mainly found to be of capillary type ( $\mathrm{n}=29,7.9 \%$ of benign tumours). Pyogenic granuloma, a variant of capillary hemangioma was predominantly seen $(n=26,7.1 \%)$, which showed surface ulceration and lobules of capillaries in the dermis. About $36 \%$ of these lesions were clinically diagnosed as hemangioma and the remaining were variably diagnosed as granuloma, chalazion, papilloma, or cyst. Tumours of neural origin were less common accounting for only $3.9 \%(n=18)$ of all neoplasms. Among these, neurofibroma $(n=12,3.3 \%$ of benign tumours) was the frequently seen benign peripheral nerve sheath tumour which was composed of spindled cells with wavy nuclei in a collagenous stroma. Myxoid changes and mast cell infiltration were also common findings. Two of them were of plexiform variant which showed tortuous and swollen neural bundles in the background of myxoid to collagenous stroma. Less common were schwannoma $(n=4)$ and solitary circumscribed neuroma $(n=2)$. Other common soft tissue tumours included fibroepithelial polyp $(\mathrm{n}=8,2.2 \%$ of benign tumours) and lipoma $(\mathrm{n}=6,1.6 \%$ of benign tumours). One case of fibrolipoma was identified as a variant of lipoma. Dermatofibroma and solitary fibrous tumour were only one each accounting for $<1 \%$ of benign tumours. Histiocytic lesions were altogether $9(1.9 \%$ of all tumours) which included 6 cases of xanthelasma, one juvenile xanthogranuloma and one xanthoma. All of the xanthelasmas were encountered in females mostly involving the upper eyelid. Benign lymphoid lesions were very less commonly encountered comprising of three cases of reactive lymphoid hyperplasia.

Precursor lesions of the eyelid were predominantly actinic 
Table 4: Appendageal proliferation/tumours: Histological classification and their demographic and topographic distribution $(\mathrm{n}=100,21.8 \%)$

\begin{tabular}{|c|c|c|c|c|c|c|c|}
\hline Type of non-neoplastic lesions & No. cases & $\begin{array}{l}\text { All Tumors } \\
(\%)\end{array}$ & $\begin{array}{l}\text { All lesions } \\
(\%)\end{array}$ & $\begin{array}{c}\text { Mean age } \\
\text { (range years) }\end{array}$ & $\begin{array}{c}\text { Peak age interval } \\
\text { years }\end{array}$ & $\begin{array}{l}\text { Sex ratio } \\
\text { (F:M) }\end{array}$ & $\begin{array}{l}\text { Location } \\
\text { (UL/LL) }\end{array}$ \\
\hline \multicolumn{8}{|c|}{ Appendageal tumour with eccrine and apocrine differentiation $(n=46)$} \\
\hline Hydrocystoma & 36 & 7.8 & 5.1 & $43.2(10-72)$ & $51-60$ & $1: 1$ & $1.2: 1$ \\
\hline Mixed tumour & 5 & 1.1 & 0.7 & $46.4(23-71)$ & $21-30$ & $4: 1$ & $1.5: 1$ \\
\hline Hidradenoma & 2 & 0.4 & 0.3 & $37(31-43) ; 8$ & $31-40 ; 41-50$ & $2: 0$ & $2: 0$ \\
\hline Cylindroma & 1 & 0.2 & 0.1 & 68 & $>60$ & $0: 1$ & $0: 1$ \\
\hline $\begin{array}{l}\text { Syringocystadenoma } \\
\text { papilliferum }\end{array}$ & 1 & 0.2 & 0.1 & 78 & $>60$ & $0: 1$ & MC \\
\hline Syringoma & 1 & 0.2 & 0.1 & 56 & $51-60$ & $1: 0$ & $1: 0$ \\
\hline \multicolumn{8}{|c|}{ Appendageal tumour with follicular differentiation $(\mathrm{n}=16)$} \\
\hline Pilomatrixoma & 14 & 3 & 2 & $22.8(4-53)$ & $11-20$ & $3.7: 1$ & $6: 1$ \\
\hline Dilated pore of Winer & 1 & 0.2 & 0.1 & 24 & $21-30$ & $0: 1$ & $1: 0$ \\
\hline $\begin{array}{l}\text { Basaloid follicular } \\
\text { harmartoma }\end{array}$ & 1 & 0.2 & 0.1 & 26 & $21-30$ & $0: 1$ & $1: 0$ \\
\hline \multicolumn{8}{|c|}{ Appendageal tumour with sebaceous differentiation $(n=38)$} \\
\hline Sebaceous hyperplasia & 9 & 2 & 1.3 & $47.8(25-72)$ & $21-30 ; 41-50 ;>60$ & $1: 1.3$ & $3.5: 1$ \\
\hline Steatocystoma & 6 & 1.3 & 0.9 & $23.6(18-27)$ & $21-30$ & $1: 5$ & $1: 1$ \\
\hline Nevus sebaceous & 1 & 0.2 & 0.1 & 42 & $41-50$ & $1: 0$ & $1: 0$ \\
\hline Sebaceous adenoma & 1 & 0.2 & 0.1 & 55 & $51-60$ & $0: 1$ & $\mathrm{MC}$ \\
\hline Sebaceous carcinoma & 21 & 4.6 & 3 & $61.2(30-82)$ & $>60$ & $2.5: 1$ & $3: 1$ \\
\hline
\end{tabular}

*female:male; †upper eyelid/lower eyelid; ;medial canthus(location)

keratoses $(\mathrm{n}=10)$ followed by squamous cell carcinoma in situ $(\mathrm{n}=6)$. Cases with actinic keratoses had histological features showing acanthosis, hyperkeratosis, and papillomatosis with mild to moderate dysplastic features. Squamous cell carcinoma in situ, histologically comprised of atypical squamous cells involving the full thickness of epidermis with or without keratin pearl formation and cytoplasmic keratinization. Two cases of seborrheic keratosis and squamous papilloma, one each, were considered precursor lesions as they developed moderate dysplasia.

The received specimen of the histologically proven malignant tumours were mainly excisional biopsy [basal cell carcinoma $(B C C ; n=34)$, sebaceous carcinoma $(n=19)$, squamous cell carcinoma (SCC; $n=8)$, lymphoma $(n=2)$, melanoma $(n=2)$, rhabdomyosarcoma $(n=1)]$. Exenteration of the eyeball was done for each case of BCC, sebaceous carcinoma, and SCC. The remaining seven cases of malignant tumours were received as incisional biopsy specimens.

Malignant tumours of epidermal origin were the most common malignant neoplasms which accounted for $63.2 \%$ $(\mathrm{n}=48)$ of malignant lesions; $\mathrm{BCC}$ being the commonest histologic type ( $\mathrm{n}=38 ; 50 \%$ of malignant tumours) were predominantly found on the lower eyelid. Histologically, the common architecture was mostly islands, solid nests, lobules, and sheets with an adenoid pattern comprising basaloid cells. Histologic variants included pigmented $(\mathrm{n}=8)$, basosquamous carcinoma $(\mathrm{n}=2)$ and keratotic $(\mathrm{n}=1)$. Pigmented variants had foci of areas with heavily laden tumour cells in the lobules and melanophages in the dermis (fig. 2A). Basosquamous carcinoma showed composite histologic features of BCC and squamoid differentiation (fig. 2B). Keratotic BCC showed nests of basaloid tumour cells with abrupt central keratinization. The common gross feature of BCC was predominantly ulcerated nodule $(n=17)$ with an average maximum dimension of $1.5 \mathrm{~cm}$ (range, 0.3 $3.8 \mathrm{~cm}$ ). Pigmented variants were mostly blackish or partly showed black colouration. The patients with basosquamous variant were both below the age of 60 years ( 47 and 55 years) presenting with gross finding as an ulcerated mass and lobulated mass respectively. One BCC was a recurrent tumour. Of 35 cases, marginal tissue assessment showed 19 cases (18 cases of excisional biopsy and one exenterated specimen) with free margins.

Sebaceous carcinoma was the second most common malignant tumour $(\mathrm{n}=21 ; 27.6 \%)$ with a predilection for the upper eyelid $(n=16)$. It ranged from well to poorly differentiated. Moderately differentiated tumours predominated $(n=12)$ having few foci of areas which showed differentiated sebaceous carcinoma cells. Histologic patterns comprised predominantly variable-sized lobules followed by mixed lobular and comedocarcinoma. Well-differentiated tumours $(\mathrm{n}=4)$ show well-demarcated lobules with frequently recognizable atypical sebaceous cells consisting of bubbly or vacuolated cytoplasm (Fig. $3 A)$. Poorly differentiated tumours $(n=5)$ had marked pleomorphism, high mitotic count up to 28/HPF including atypical mitoses and infiltrative pattern. Intraepithelial spread to conjunctiva or epidermis or both were frequently 
Table 5: Histological classification of neoplasms: Melanocytic tumours, soft tissue tumours and others

\begin{tabular}{|c|c|c|c|c|c|c|c|}
\hline Type of non-neoplastic lesions & No. cases & $\begin{array}{l}\text { All Tumors } \\
(\%)\end{array}$ & $\begin{array}{l}\text { All lesions } \\
(\%)\end{array}$ & $\begin{array}{c}\text { Mean age } \\
\text { (range years) }\end{array}$ & $\begin{array}{c}\text { Peak age } \\
\text { interval years }\end{array}$ & $\begin{array}{l}\text { Sex ratio } \\
\text { (F:M) }\end{array}$ & $\begin{array}{l}\text { Location } \\
\text { (UL/LL) }\end{array}$ \\
\hline \multicolumn{8}{|c|}{ Melanocytic tumour $(n=110,24 \%)$} \\
\hline \multicolumn{8}{|l|}{ Melanocytic nevi (n=108) } \\
\hline Intradermal nevi & 96 & 21 & 13.7 & $41.3(16-83)$ & $31-40$ & $3: 1$ & $1.4: 1$ \\
\hline Compound nevi & 12 & 3 & 1.7 & $26.7(6-74)$ & $21-30$ & $2: 1$ & $1.2: 1$ \\
\hline Melanoma & 2 & 0.4 & 0.3 & $44.5(5-84)$ & $<10 ;>60$ & $2: 0$ & $2: 0$ \\
\hline \multicolumn{8}{|l|}{ Vascular tumor $(n=56,2.7 \%)$} \\
\hline \multicolumn{8}{|l|}{ Haemangioma $(\mathrm{n}=54)$} \\
\hline Capillary haemangioma & 29 & 6.3 & 4.1 & $32.1(6-70)$ & $11-20 ; 31-40$ & $1: 1.6$ & $2.1: 1$ \\
\hline Cavernous haemangioma & 4 & 0.9 & 0.6 & $38.8(17-58)$ & $11-20$ & $1: 3$ & $4: 0$ \\
\hline Intramuscular haemangioma & 1 & 0.2 & 0.1 & 37 & - & $0: 1$ & $0: 1$ \\
\hline Spindle cell haemangioma & 1 & 0.2 & 0.1 & 30 & $21-30$ & $1: 0$ & MC \\
\hline Others & 19 & 4.1 & 2.7 & $31(6-700$ & $11-20$ & $1.7: 1$ & $1.3: 1$ \\
\hline Lymphangioma & 2 & 0.4 & 0.3 & $19(19-19)$ & $11-20$ & $1: 1$ & $1: 1$ \\
\hline \multicolumn{8}{|l|}{ Neural tumour $(\mathrm{n}=18,2.7 \%)$} \\
\hline Neurofibroma & 12 & 2.6 & 1.7 & $33.2(9-740$ & $21-30$ & $1: 1$ & $5: 1$ \\
\hline Schwannoma & 4 & 0.9 & 0.6 & $35(7-65)$ & - & $1: 1$ & $1: 3$ \\
\hline Solitary circumscribed neuroma & 2 & 0.4 & 0.3 & $49(45-53)$ & - & $1: 1$ & $2: 0$ \\
\hline \multicolumn{8}{|c|}{ Fibroblastic, fibrohistiocytic tumour $(\mathrm{n}=10,2.2 \%)$} \\
\hline Fibroepithelial polyp & 8 & 1.7 & 1.1 & $38.9(23-59)$ & $21-30$ & $1.7: 1$ & $2.5: 1$ \\
\hline Dermatofibroma & 1 & 0.2 & 0.1 & 45 & $41-50$ & $1: 0$ & $1: 0$ \\
\hline Solitary fibrous tumour & 1 & 0.2 & 0.1 & 45 & $41-50$ & $0: 1$ & $1: 0$ \\
\hline \multicolumn{8}{|l|}{ Miscellaneous $(n=7,1.5 \%)$} \\
\hline Rhabdomyosarcoma & 1 & 0.2 & 0.1 & 14 & $11-20$ & $0: 1$ & $\mathrm{MC}$ \\
\hline Lipoma & 6 & 1.3 & 0.8 & $33.6(14-72)$ & $21-30$ & $5: 1$ & $1: 1$ \\
\hline \multicolumn{8}{|c|}{ Lymphoid tumour/Tumour like lesions $(\mathrm{n}=6,1.3 \%)$} \\
\hline Reactive lymphoid hyperplasia & 3 & 0.7 & 0.4 & $33.7(14-72)$ & $11-20$ & $2: 1$ & $2: 1$ \\
\hline Non-Hodgkin Lymphoma & 3 & 0.7 & 0.4 & $50(34-72)$ & $>30$ & $1: 2$ & $2: 1$ \\
\hline \multicolumn{8}{|l|}{ Histiocytic lesions $(\mathrm{n}=\mathbf{9}, \mathbf{2 \%})$} \\
\hline Xanthelasma & 6 & 1.3 & 0.9 & $44.2(27-52)$ & $41-60$ & $6: 0$ & $5: 1$ \\
\hline Xanthogranuloma & 2 & 0.4 & 0.3 & $16(2-30)$ & $<10 ; 21-30$ & $1: 1$ & LC \\
\hline Xanthoma & 1 & 0.2 & 0.1 & 4 & $<10$ & $0: 1$ & $\mathrm{MC}$ \\
\hline
\end{tabular}

*female: male; †upper eyelid/lower eyelid; łmedial canthus; §medial canthus: upper eyelid; ||upper eyelid: medial canthus; $\mid$ Ilateral canthus

seen predominantly in moderate to poorly differentiated tumours $(\mathrm{n}=13)$ as shown in figure 3B. One basaloid variant (considered as poorly differentiated) and one sebaceous carcinoma with squamoid differentiation were also found. Grossly, average dimension was $1.2 \mathrm{~cm}$ (range, $0.4-3 \mathrm{~cm}$ ). Most of the poorly differentiated tumours grossly appeared grey-white while, well to some moderately differentiated tumours appeared typically yellow to creamy in colour on the cut section. Recurrent sebaceous carcinoma comprised of three cases graded moderate to poorly differentiated, and were associated with intraepithelial spread, which developed within the two years of an interval of post-excisional biopsy. One of these recurrent tumours underwent an exenteration procedure due to the extensive involvement of both upper and lower eyelids and margins were involved by the tumour. Out of 19 cases of excised sebaceous carcinoma, only 5 of them had free marginal tissue.
SCC was the third common malignant tumour $(n=11$; $14.5 \%$ ) with a slight preference for the lower eyelid (Table 3 ) and was mostly graded as well to moderately differentiated. Its variants included one keratoacanthoma, one spindle cell carcinoma, and one acantholytic (adenoid) histologic subtype. The case of keratoacanthoma (well-differentiated variant) had typical histologic features demonstrating asymmetrical tumour which was composed of a central crater filled with keratin and epidermal lipping on both sides of the keratin core (Fig. 2C). Invaginated epidermis consisted of squamous cells with pale eosinophilic cytoplasm showing mild nuclear atypia and rare mitosis. The spindle cell carcinoma was encountered in an exenterated eyeball specimen which was histologically composed of widely infiltrative diffuse sheets and branching cords of pleomorphic spindled cells having dense eosinophilic cytoplasm and hyperchromatic elongated nuclei with 
Table 6. Frequency of different benign eyelid lesions reported in various studies*

\begin{tabular}{|c|c|c|c|c|c|c|c|c|c|}
\hline & $\begin{array}{l}\text { Present } \\
\text { study }\end{array}$ & $\begin{array}{l}\text { Bastola et } \\
\text { al. }{ }^{23}\end{array}$ & $\begin{array}{c}\text { Mohan } \\
\text { and Letha } \\
9\end{array}$ & $\begin{array}{l}\text { HUang et } \\
\quad \text { al. }{ }^{22}\end{array}$ & Ho et al. ${ }^{25}$ & $\begin{array}{l}\text { Chi and } \\
\text { Back }^{26}\end{array}$ & $\begin{array}{l}\text { Alfaky }^{5} \\
2012\end{array}$ & $\begin{array}{l}\text { Paul et al. } \\
2011\end{array}$ & $\begin{array}{l}\text { Coroi et } \\
\text { al. }{ }^{27} 2010\end{array}$ \\
\hline Period $\dagger$ & 2016-19 & $2008-12$ & $2006-15$ & $1995-15$ & 2000-09 & 2000-02 & 2003-08 & 2004-07 & $2000-07$ \\
\hline Country & Nepal & Nepal & India & Taiwan & Hongkong & $\begin{array}{l}\text { South } \\
\text { Korea }\end{array}$ & $\begin{array}{l}\text { Saudi } \\
\text { Arabia }\end{array}$ & USA & Roman \\
\hline $\begin{array}{l}\text { Total benign } \\
\text { lesions, } \mathrm{N}\end{array}$ & 607 & 45 & 373 & 4289 & 170 & 56 & 222 & 631 & 216 \\
\hline $\begin{array}{l}\text { Melanocytic } \\
\text { Nevus (\%) }\end{array}$ & 17.7 & 15.6 & 12.6 & 22.3 & 30.6 & 57.1 & 8 & 12.5 & 2.3 \\
\hline $\begin{array}{l}\text { Epidermal } \\
\text { Cyst (\%) }\end{array}$ & 11 & 17.8 & 15.8 & 9.6 & 8.2 & 5.3 & 9 & 7.3 & 8.3 \\
\hline $\begin{array}{l}\text { Haemangioma } \\
(\%)\end{array}$ & 8.9 & 15.6 & 5.4 & 1.1 & 4.7 & 1.8 & 1 & - & 0.9 \\
\hline $\begin{array}{l}\text { Dermoid cyst } \\
(\%)\end{array}$ & 8.2 & 27 & 6.2 & - & - & 1.8 & - & - & - \\
\hline Chalazion (\%) & 6.7 & 2.2 & 13.4 & - & 3 & - & 20.2 & 14.1 & 13.9 \\
\hline $\begin{array}{l}\text { Squamous } \\
\text { Papilloma (\%) }\end{array}$ & 6.4 & - & 10.2 & 3.4 & - & 5.4 & 12.2 & - & 38.9 \\
\hline $\begin{array}{l}\text { Hydrocystoma } \\
(\%)\end{array}$ & 5.9 & 4.4 & 3.5 & - & - & 1.8 & 29.2 & 8.9 & - \\
\hline $\begin{array}{l}\text { Seborrheic } \\
\text { Keratosis (\%) }\end{array}$ & 5.1 & 4.4 & 4.8 & 12.6 & 14.7 & 6.1 & 5.9 & 20.3 & 5.1 \\
\hline Others (\%) & 30.1 & 13 & 28.1 & 51 & 38.8 & 10.7 & 14.4 & 36.9 & 30.6 \\
\hline
\end{tabular}

*Precursor lesion has been removed from the published reports for the comparison purpose; †period of data collection

prominent nucleoli. The focal area showed stratification and keratin pearl formation supporting the squamoid differentiation. The acantholytic variant had histologic features showing dermis with infiltration of acantholytic atypical squamous cells giving a pseudoglandular pattern. Grossly, the average size of SCC was $1.2 \mathrm{~cm}$ (range, 0.2$4 \mathrm{~cm}$ ). Among the 8 cases of excised biopsy of SCC, only 2 of them had free marginal tissue while one exenterated specimen had all free surgical margins.

Other less common malignant tumour consisted of three cases of Non-Hodgkin lymphoma (NHL), two cases of malignant melanoma, and one case of rhabdomyosarcoma. Two patients, aged 34 years and 72 years with NHL, were histologically diagnosed as small lymphocytic lymphoma with differential diagnosis of mantle cell lymphoma. The first patient, aged 34 years was confirmed to be mantle cell lymphoma by immunohistochemistry. The third patient, aged 44 years was histologically diagnosed as primary cutaneous marginal zone (MALT) lymphoma with differential diagnosis of lymphoplasmacytic lymphoma. However, the immunohistochemistry report could not be traced for the specific subtype of lymphoma in these two patients. Two cases of malignant melanoma diagnosed as epithelioid and amelanotic variant were seen in two extremes of ages i.e. 5 and 84 years respectively. Amelanotic variant composed of a dermal proliferation of solid nests and lobules of polygonal cells with round to elongated nuclei and macronucleoli along with high mitotic activity and marginal tissue was involved. One encapsulated soft tissue sarcoma involving the right medial canthus was embryonal rhabdomyosarcoma detected in a male patient at the age of 14 years. Marginal tissue was free of tumour.

Of the 76 malignant tumours, 49 cases were correctly diagnosed clinically. Six malignant cases were clinically misdiagnosed as benign lesions and 14 of them had a nonspecific diagnosis as eyelid mass. Diagnostic accuracy was $72 \%$ (51 out of 71 clinically suspected malignancy) for malignant lesions. The diagnostic accuracy of BCC was $85.3 \%$ (29/34 cases of clinically suspected BCC). The remaining five cases were histologically proven to be benign (seborrheic keratosis, lichenoid keratosis, and haemangioma), malignant (SCC), and precursor lesion (SCC in situ). On the contrary, histologically confirmed BCC were clinically misdiagnosed as a benign lesion (dermoid cyst) and other types of malignant lesions (melanoma and lymphoma). The diagnostic accuracy of sebaceous carcinoma was $65 \%$ (15 out of 23 clinically suspected sebaceous carcinoma). Of the eight cases of clinically suspected sebaceous carcinoma, seven of them were histologically proven to be benign lesions such as epidermal cyst, chalazion, choristoma, sebaceous hyperplasia, and nevus, and one as precursor lesion (squamous cell carcinoma in situ). Only one case of histologically proven sebaceous carcinoma was clinically misdiagnosed as a benign lesion (chalazion). It was also misdiagnosed as other malignant lesions such as BCC and SCC. The diagnostic accuracy of SCC was about 50\% (3/ 6 cases of clinically suspected SCC). One clinically suspected SCC was histologically diagnosed as granuloma and two of them as sebaceous carcinoma. Histologically proven SCC were clinically misdiagnosed as benign lesions (nevus and 


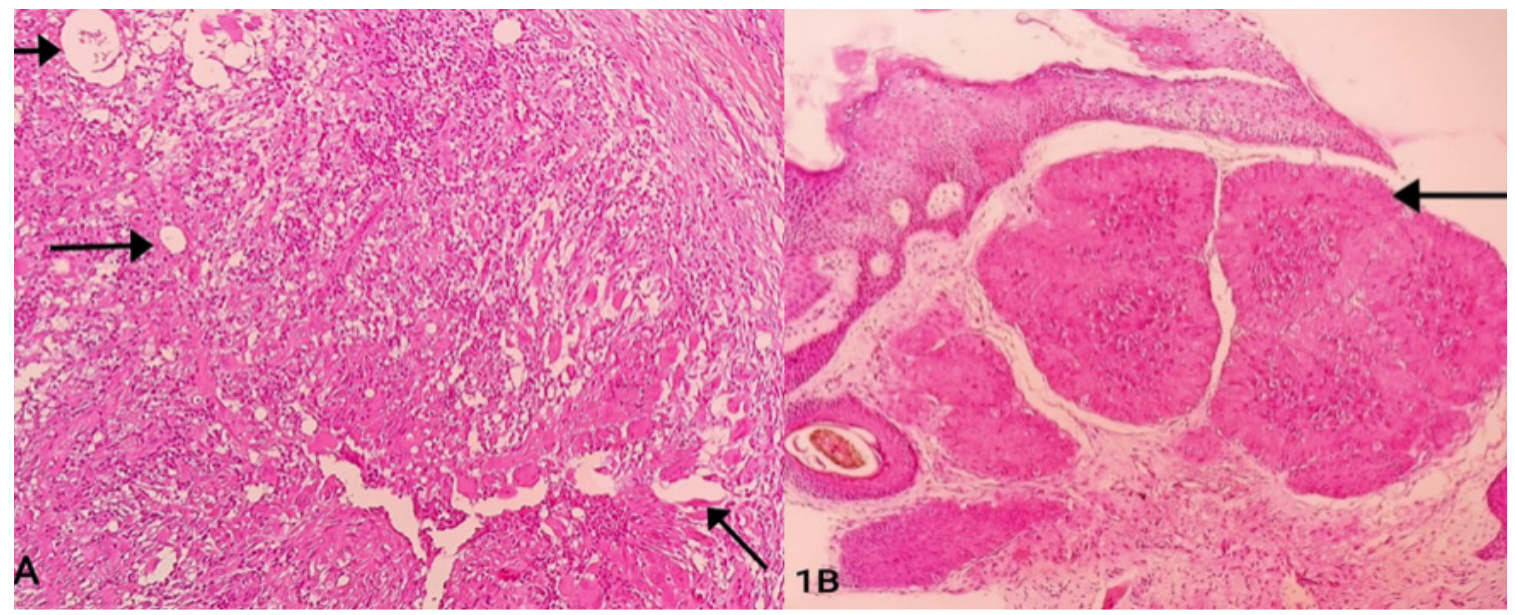

Figure 1: Benign eyelid lesions: A. Chalazion showing granulomatous inflammation around fat vacuoles (arrows). (HE stain, x100); B. Molluscum contagiosum (infectious disease) with lobules of squamous cells consisting of molluscum bodies (arrow).(HE stain, x100); C. Melanocytic nevus, intradermal type is composed of nests of nevus cells in the dermis; few multinucleated giant cells (arrows) are seen, however of no significance. (HE stain, x400)

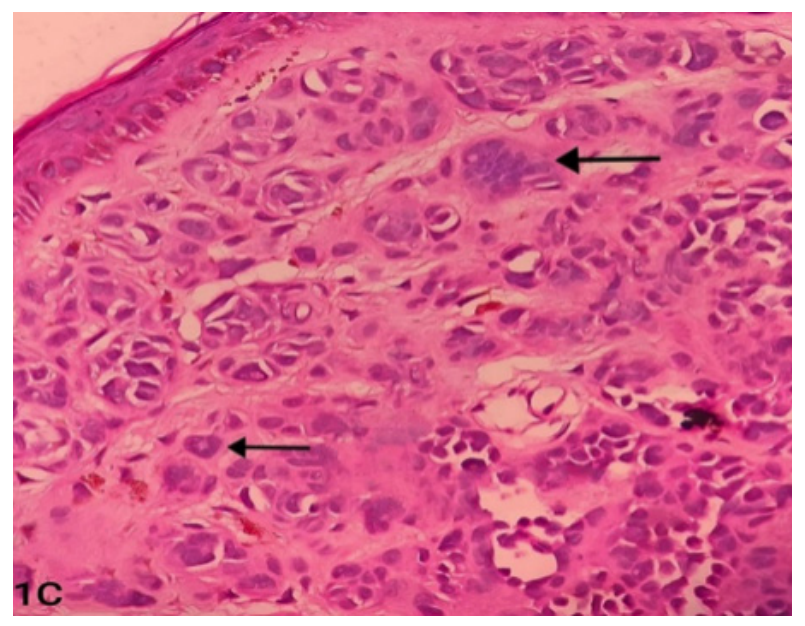

papilloma) and malignant lesion (sebaceous carcinoma). Precursor lesions such as actinic keratosis were mostly misdiagnosed as benign lesions such as a wart, cutaneous horn, nevus, and papilloma, while squamous cell carcinoma in situ was clinically suspected as BCC, sebaceous carcinoma, or papilloma. Diagnostic accuracy for benign lesions was $97 \%$.

\section{DISCUSSION}

Eyelid lesions are very common in ophthalmology practice and various cutaneous lesions are encountered due to their histologic similarity to the skin. Eyelid cancers represent approximately 5 to $10 \%$ of all cutaneous malignant tumours. ${ }^{18}$ Globally, several studies with large case series have documented variable frequency of different eyelid lesions in Western and Asian countries. So far, we have a sparse report on eyelid lesions. This study comprised a total of 701 eyelid lesions in 692 patients which included a diverse population of the Central and Eastern region of Nepal. To our knowledge, this is a large study demonstrating the histopathologic spectrum and their demographic distribution in a diverse ethnic population of Nepal.
Benign lesions $(87 \%)$ were far more common than malignant ones $(10.8 \%)$ in accordance with previous studies worldwide that ranged from 71-91\%. ${ }^{7,9,20,22}$ Bastola et al. ${ }^{23}$ from Nepal, conducted a multicenter study which showed $78.9 \%$ and is comparable to our study. In contrast, Lavaju et al. ${ }^{24}$ evaluated eyelid lesions in a tertiary hospital located in the Eastern region of Nepal and found a lower frequency of $42.8 \%$ for benign eyelid lesions. It might be due to the patient's preference for an eye care centre (which is available in this region) for ophthalmic pathologies and more so, benign eyelid lesions are removed for aesthetic reasons with increased chances of a visit to a specialized eye hospital than the general hospital. Female preponderance was observed in our study consistent with similar studies conducted in the $\mathrm{US}^{6}$, India ${ }^{9}$, and Hongkong ${ }^{25}$.

The comparison of the frequency of various benign eyelid lesions including both non-neoplastic lesions and benign neoplasms, published in different parts of the world are presented in Table 6 . We found melanocytic nevus (17.7\%) as the most common benign histologic diagnosis followed by an epidermal cyst, haemangioma, dermoid cyst, chalazion, and squamous papilloma. It is also reported as the most common benign eyelid lesion in the studies from Taiwan ${ }^{22}$, Hongkong ${ }^{25}$, South Korea ${ }^{26}$, and Latin America ${ }^{20}$. There is some variation in other studies regarding the most common benign eyelid lesion. Coroi et al. ${ }^{27}$ (Romania) has reported squamous papilloma whereas seborrheic keratosis, epidermal cyst, dermoid cyst, and hydrocystoma are the commonest benign eyelid lesions in the study done by Paul et al. ${ }^{7}$ (USA), Mohan and Letha ${ }^{9}$ (India), Bastola et al. ${ }^{23}$ (Nepal) and Al Faky ${ }^{5}$ (Saudi Arabia) respectively. Al-Faky ${ }^{5}$ states that hydrocystoma or sudoriferous cyst as the most common finding amongst benign lesions in their study could be due to exposure to the hot and dry climate in the Arabian country.

Epidermal tumour was the commonest neoplasm among all tumours in keeping with the studies in India 28 and 

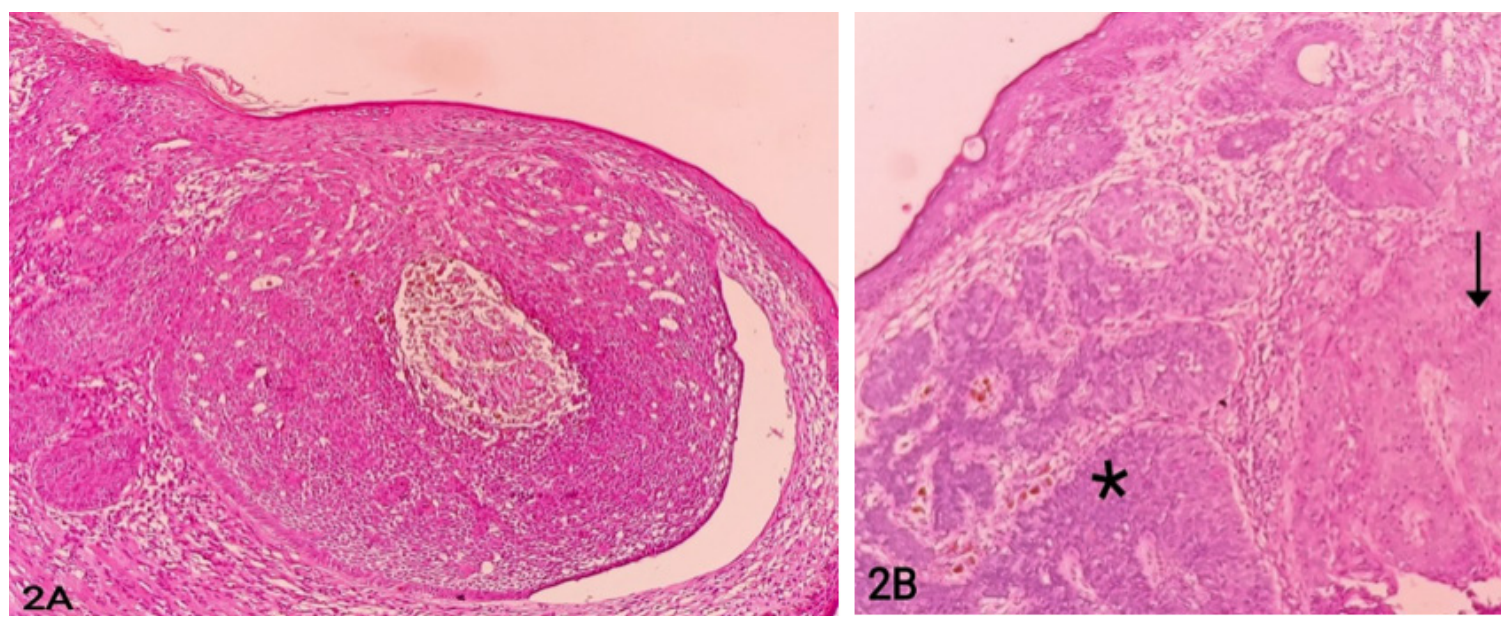

Figure 2: Malignant epidermal tumours of eyelid: A. Basal cell carcinoma, pigmented variant comprising of lobules of atypical basaloid cells, some of which are laden with cytoplasmic melanin pigment along with peripheral nuclear palisading and retraction artefact. (HE stain, x100); B. Basosquamous carcinoma, variant of basal cell carcinoma which is characterized by presence of both features of basal cell carcinoma (asterisk), and squamoid differentiation (arrow). (HE stain, x100); C.Keratoacanthoma (Well differentiated variant of squamous cell carcinoma) showing keratin filled central crater (arrow) and epidermal lipping on both sides of the core. (HE stain, x100).

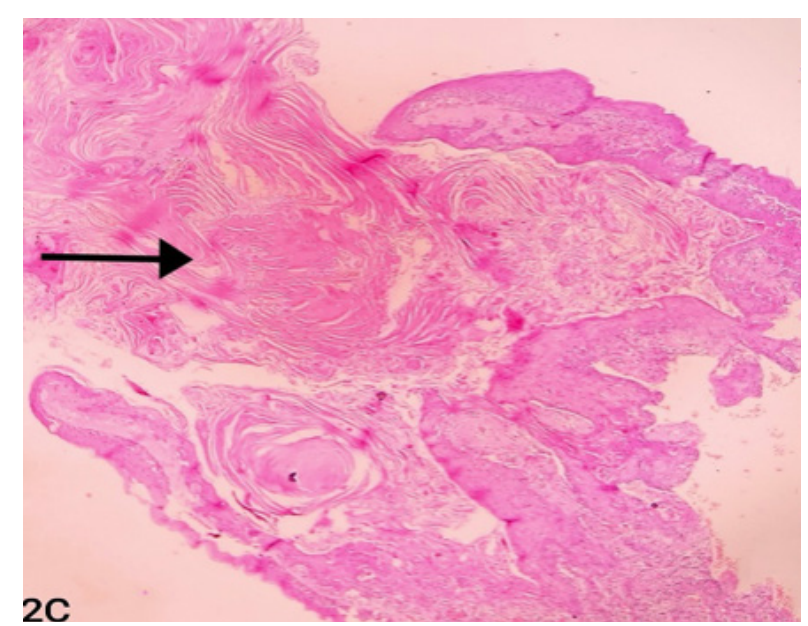

China 29. But still, the tumour of melanocytic origin i.e. melanocytic nevus ranked first among the benign neoplasms accounting for $29.6 \%$ of the benign tumours in our study. Yu et al. 29 has claimed that nevus is the most common benign tumour in the Asian population, consistent with our study. In contrast, a large cohort study of 5504 cases reviewed by Deprez and Uffer 11 from Switzerland as well as the study by Gundagon et al. ${ }^{24}$ from Turkey have shown squamous papilloma (26\%) as the commonest benign tumour. We found intradermal nevus as the most common histologic variant of melanocytic nevus, in congruence with several previous studies. ${ }^{20,22,25,26,29}$

Benign lesions were more common below 40 years of age wherein, non-neoplastic lesions were frequently encountered under the age of 10 years showing slight male predominance in our study. This could be explained due to the increased frequency of a developmental malformation, i.e., dermoid cyst in this age group in agreement with Mohan and Letha ${ }^{9}$ and Giri et al. ${ }^{21}$ However, one study 31 which was conducted in a paediatric age group over 10 years in Southern Taiwan, reported epidermal cyst as the commonest lesion followed by dermoid cyst. We found benign neoplasms more frequently at the age interval of 2130 years. Coroi et $\mathrm{a}^{27}$ reported benign neoplasms with a peak age interval of 31-40 years. Several previous studies have observed benign tumours frequently occurring below 50 years. ${ }^{8,29,32}$ The most preferential location of the benign lesion was the upper eyelid in our study, consistent with other studies. ${ }^{19,21,27}$ Whereas, Kerstan et $\mathrm{al}^{6}$ have reported a fairly even distribution between upper and lower eyelid lesion.

We found actinic keratosis (precursor lesion) accounting for $1.4 \%$ of all lesions and $2.2 \%$ of all tumours, in keeping with Ho et al ${ }^{25}$ and Yu et al. ${ }^{29}$ The mean age was 45.7 years. Deprez and $\mathrm{Uffer}^{11}$ reported higher frequency accounting for $5 \%$ of epidermal tumours in the elderly. Squamous cell carcinoma in situ accounted for only $0.9 \%$ which is also less in other studies ${ }^{11,22,30}$ ranging from $0.1 \%$ to $0.3 \%$ of all eyelid lesions.

In agreement with previous studies from India ${ }^{9,19}$ and Hongkong ${ }^{25}$, malignant eyelid lesions accounted for only $10.8 \%$ of all lesions. The frequency of these lesions was found to be $16 \%$ out of all neoplasms, in accordance with previous large retrospective studies. ${ }^{11,29}$ Some studies have reported a higher frequency of malignant lesions up to $29 \%{ }^{7,20}$ A 21 -year review in the Chinese population by Lin et $\mathrm{a}^{33}$ demonstrated an increase in the incidence rate of eyelid malignancy from 1.5 million in 1979 to 5.1 million in 1999 which indicates that there is an increasing trend of eyelid cancer. Malignant eyelid lesion is the disease of the elderly accepted worldwide ${ }^{7,29}$ which corroborates with our finding. It occurred predominantly above $>60$ years of age in concordance with previous studies. ${ }^{6,8,22,27,32}$

The comparison of the frequency of common malignant lesions reported in various countries is presented in Table 7. $\mathrm{BCC}$ was the most common malignant lesion $(50 \%)$ 


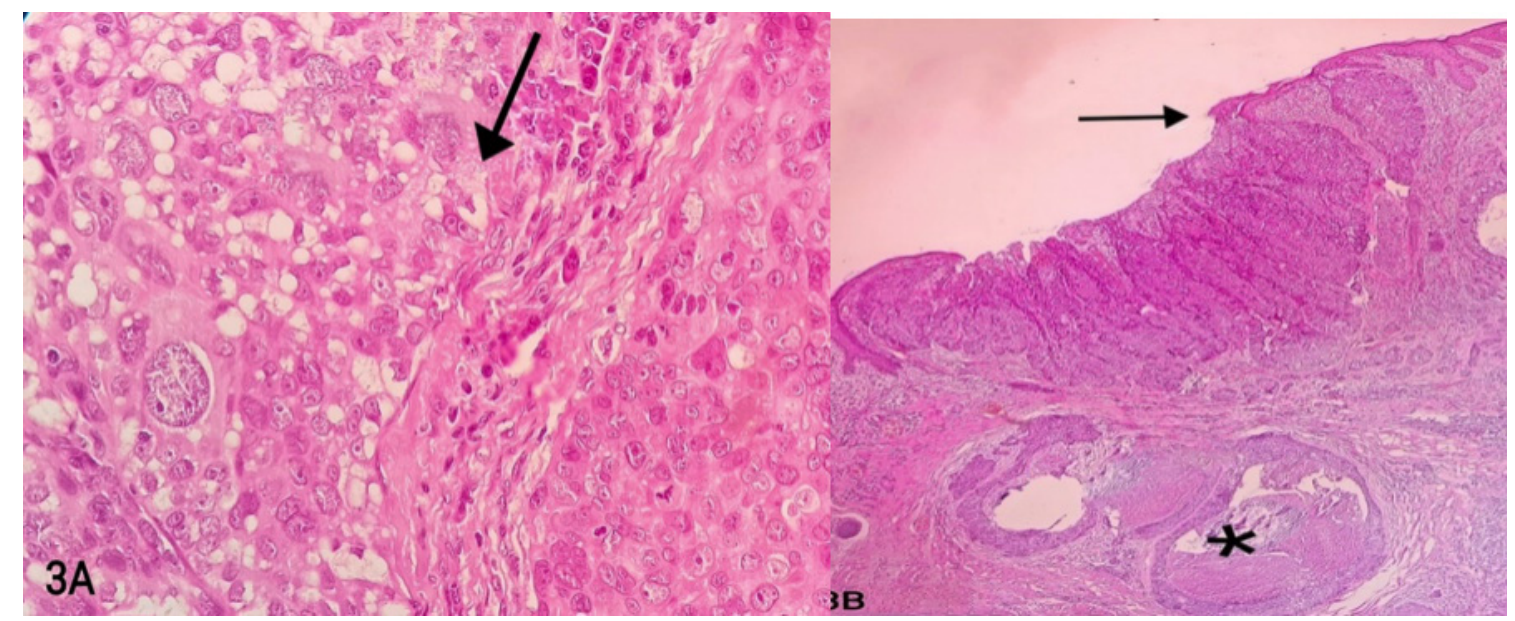

Figure 3: Sebaceous carcinoma of the eyelid (malignant adnexal tumour with sebaceous differentiation): A. Lobules of atypical pleomorphic cells, some with vacuolated cytoplasm featuring sebaceous differentiation (left side, shown by arrow) (HE stain, x400); B. Lobules of tumour cells in the dermis showing comedocarcinoma pattern (asterisk) and intraepithelial spread of tumour (arrow), an important feature indicating poor prognosis (HE stain, x100).

and it accounted for $8.3 \%$ of all eyelid lesions with an increased frequency above 60 years showing a mean age of 66.1 years in the present study. Cook and Bartley ${ }^{18}$ have reported the higher incidence of $\mathrm{BCC}$ in individuals older than 70 years which he explained to be associated with cumulative solar exposure that increases with age. The frequency of BCC in our study is similar to previous studies 22,25,29 conducted in the Chinese and Taiwanese populations. Lavaju et al. ${ }^{24}$ from Nepal also reported BCC as the most common malignant tumour. In contrast, Western countries have a higher incidence constituting 70 to $90 \%$ of malignant tumours. ${ }^{6,7,11,27}$ The higher incidence in the Western and American populations has been attributed to the geographic altitude and difference in the skin type. Lin et al ${ }^{33}$ suggested that increased incidence of BCC in fair-skinned Caucasian is due to their skin type I and II according to Fitzpatrick's classification and comparatively low in Asian population which belong to skin type III and IV.

Previous studies ${ }^{8,11,18,22,32}$ from different parts of the world have demonstrated BCC showing with male preponderance which is attributed to frequent outdoor activity in males or use of sunscreen by females as a protective factor against UV radiation. A higher incidence of males with HIV infection or even sex ratio in the given population is also suggested for increasing tendency of developing BCC, particularly in males. ${ }^{711}$ In contrast, we found that females were affected more than males (Table 3) in agreement with Kalliki et $\mathrm{al}^{34}$ from India and Domingo et $\mathrm{al}^{35}$ from the Philippines. Lee et $\mathrm{al}^{36}$ demonstrated an increased incidence rate in females over 28 years from 1968 to 1995 in Singapore which he relates to the increase of women in the workforce over the years. Therefore, it is plausible that increased frequency in females could be due in part to the increased frequency of working outdoor for earning rather than confined to household work and less use of sunscreen by females in our community in comparison to those in the Western world. Aggressive variants of $\mathrm{BCC}$, such as Basosquamous carcinoma, were uncommon in this study which is also observed by previous studies $^{8,10,11,24}$, however its recognition is important because of its high rate of recurrence and metastatic potential to lymph nodes.

The second most common malignant neoplasm was sebaceous carcinoma (27.6\%) which is close to other studies from China ${ }^{29}$, Taiwan ${ }^{22}$, and some of the studies from India. ${ }^{37}$ A recent study ${ }^{13}$ conducted in the Eastern region of Nepal on malignant eyelid tumours reported an equal frequency of sebaceous carcinoma and BCC which accounted for 35.7\%. Higher prevalence is observed by Kumar ${ }^{10}$ and Bastola et $\mathrm{al}^{22}$ and has shown sebaceous carcinoma as the most common malignant lesion in the population of the SouthWestern region of Nepal accounting for $40.5 \%$ and $41.6 \%$ respectively. In contrast, its frequency is comparatively low $(14.2 \%)$ in another study from Eastern Nepal 24 ranking it as the third common malignant tumour. Several studies from India have reported sebaceous carcinoma as the most common tumour with a higher frequency reaching up to $67 \% \cdot{ }^{8,21,28,34,38}$ Kaliki et $\mathrm{al}^{34}$ proposed that the incidence of sebaceous carcinoma is higher in the Asian population compared to Caucasians and stated that it could be related to race, ethnicity, and genetic predisposition. Kumar ${ }^{10}$ has assumed that the increased frequency of sebaceous carcinoma in his study is due to the influence of geographical and environmental factors in the Terai plain which is dominated by people of Indian origin, similar to the Indian population. However, Das et a ${ }^{39}$ argued that ethnicity or Asian Pacific Islander ancestry is not a risk factor for sebaceous carcinoma based on a retrospective review of 1349 cases of sebaceous carcinoma from the US-based population registry. They have suggested that the increased incidence of sebaceous carcinoma in the Asian population could be because of the relatively low number of other skin malignancies. By and large, the variation of prevalence of malignant tumor in the Nepali population when compared between the Central and Eastern region versus Western region of Nepal contemplate in future to meticulously explore the environmental factors, 
Table 7: Comparisons of frequency of common malignant eyelid tumours in various studies* in different parts of the world.

\begin{tabular}{|c|c|c|c|c|c|c|c|}
\hline Author & Country & Period & $\mathbf{N}$ & BCC (\%) & $\operatorname{SebC}(\%)$ & $\operatorname{SCC}(\%)$ & Others $(\%)$ \\
\hline Kerstan et al. ${ }^{6}, 1997$ & USA & $1988-95$ & 154 & 90.2 & 2 & 5.2 & 2.5 \\
\hline Deprez and Uffer ${ }^{11}, 2009$ & Switzerland & 1989-07 & 894 & 86.3 & 3.2 & 7.5 & 3 \\
\hline Coroi et al. ${ }^{27}, 2010$ & Romania & $2000-07$ & 255 & 72.5 & 1.9 & 19.6 & 6 \\
\hline Paul et al. ${ }^{7}, 2011$ & USA & 2004-07 & 206 & 71.8 & 7.3 & 9.7 & 11.2 \\
\hline Ho et al. ${ }^{25}, 2013$ & Hongkong & 2000-09 & 25 & 48 & 8 & 20 & 24 \\
\hline Huang et al. ${ }^{22}, 2015$ & Taiwan & $1995-15$ & 227 & 57.7 & 21.1 & 10.1 & 11 \\
\hline Yu et al. ${ }^{29}, 2018$ & China & $2002-15$ & 292 & 57.2 & 34.6 & 4.5 & 3.7 \\
\hline Prabha et al. ${ }^{38}, 2015$ & India & 2012-15 & 85 & 27 & 67 & 6 & - \\
\hline Sushma et al. ${ }^{8}, 2018$ & India & 2011-15 & 56 & 32.1 & 42.8 & 8.9 & 6 \\
\hline Kaliki et al. ${ }^{34}, 2018$ & India & $1995-16$ & 536 & 24 & 53.2 & 18.4 & 4.4 \\
\hline Anandani et al. ${ }^{37}, 2018$ & India & 2008-14 & 70 & 27.1 & 30 & 34.3 & 8.6 \\
\hline Giri et al. ${ }^{21}, 2018$ & India & $2012-18$ & 27 & 18.5 & 48.1 & 14.8 & 18.5 \\
\hline Lavaju et al. ${ }^{24}, 2009$ & Nepal & 2003-08 & 28 & 57.1 & 14.3 & 17.8 & 10.7 \\
\hline $\operatorname{Kumar}^{10}, 2010$ & Nepal & 2000-09 & 37 & 29.7 & 40.5 & 27 & 2.7 \\
\hline Bastola et al. ${ }^{23}, 2013$ & Nepal & 2008-12 & 12 & 33.3 & 41.7 & 8.3 & 16.7 \\
\hline Kafle et al. ${ }^{13} 2019$ & Nepal & 2016-19 & 28 & 35.7 & 35.7 & 28.6 & - \\
\hline Present study & Nepal & 2016-19 & 76 & 50 & 27.6 & 14.5 & 7.9 \\
\hline
\end{tabular}

*Some of the studies 10,24,29 reported histologic variants of BCC and SCC separately, therefore added up to BCC and SCC, respectively. Precursor lesion is removed from the study by Ho et al. 25 for the comparison purpose; total cases of malignant tumours

ethnicity, and genetic factors regarding eyelid malignancy. Female preponderance was strikingly high for sebaceous carcinoma, consistent with previous studies. ${ }^{8,10,12,29,34}$ The predilection for female is unknown.

Histologically, moderately differentiated sebaceous carcinoma was more common at presentation followed by a poorly differentiated tumour. Intraepithelial spread was found in $59 \%$ of cases in keeping with Shields et al ${ }^{12}$, which indicates the aggressive nature of the tumour and is well known for its high recurrence rate and metastatic potential. We found three recurrent tumours accounting for $10.7 \%$ over a period of three years. The study by Kafle et al. ${ }^{13}$ from Nepal has reported two cases of recurrent tumour (20\%) over the same period of time. The retrospective review over a period of 22 years by Kaliki et a ${ }^{34}$ has observed a $21 \%$ of recurrence rate. The longer period of study would provide more insight into the recurrence rate of malignant tumours in our population.

SCC was the third common malignant tumour comprising $14.5 \%$ of malignant tumour and $1.6 \%$ of all eyelid lesions in agreement with previous studies in India ${ }^{21,34}$ and Taiwan 22. SCC is considered the second most common tumour constituting $5 \%$ to $10 \%$ of eyelid malignant lesions in European countries and The U.S. ${ }^{6,711,18,27}$ In Nepal, the relative frequency of SCC in various regions ranged from $8 \%$ to $27 \%{ }^{10,23,24}$ The higher rates of SCC might be due to the tendency of overdiagnosis in published reports of eyelids lesions as it may resemble other growths on histological examination. ${ }^{18,36}$ Well to moderately differentiated SCC were more common at presentation, and poorly differentiated tumours were few including histologic subtypes such as acantholytic and spindle cell variant.

BCC and SCC had a preference for lower eyelids in our study and corroborates with the previous studies ${ }^{11,18}$ which is attributed to the relatively greater sun exposure of the lower eyelid than the upper eyelid. Whereas, the preferential location for sebaceous carcinoma was the upper eyelid in our study, consistent with other similar studies. ${ }^{7,8,13,22,29,34}$ This preference is obviously due to the presence of numerous meibomian glands in the upper eyelid from which the tumour originates.

Lymphoma, malignant melanoma, and rhabdomyosarcoma constituted only $7.9 \%$ of malignant lesions in this study. Prolonged sun exposure is the risk factor for BCC, SCC, and melanoma, but still, SCC and melanoma are not common when compared to $\mathrm{BCC}$ in the eyelid. Lin et $\mathrm{al}^{33}$ state that factors such as genetic susceptibility among racial groups, other environmental factors, and gene-environmental interaction might account for the differences in the frequency of these malignant cutaneous lesions in the eyelid. We did not encounter any uncommon histologic variants such as Adenoid cystic carcinoma, Mucoepidermoid carcinoma, Merkel cell carcinoma, Kaposi sarcoma reported in the other studies. ${ }^{20,34}$ It could probably be due to our relatively shorter study period.

The diagnostic accuracy was $72 \%$ for a malignant tumour in keeping with Kafle et al. ${ }^{13} \mathrm{BCC}$ and sebaceous carcinoma was relatively diagnosed correctly than SCC, with a diagnostic accuracy of $85 \%, 65 \%$, and $50 \%$ respectively. The study by 
Kerstan et al6 have shown up to $90 \%$ of diagnostic accuracy for BCC. According to the literature review ${ }^{6,18,40}$, sebaceous carcinoma may masquerade different benign lesions such as chalazion, bhlepharo-conjunctivitis, cicatricial pemphigoid, sarcoidosis, sebaceous hyperplasia, sebaceous adenomas, and malignant tumours like $\mathrm{BCC}, \mathrm{SCC}$, melanoma, etc. The ophthalmologists seemed to be well aware of these masquerade syndromes which could have led to a high index of clinical suspicion for sebaceous carcinoma in this study. It might be the reason that we found benign lesions, such as epidermal cyst, chalazion, choristoma, sebaceous hyperplasia, or nevus, clinically suspected for sebaceous carcinoma. Only one case of histologically proven sebaceous carcinoma was clinically misdiagnosed as a chalazion. BCC and SCC were also misdiagnosed clinically as dermoid cyst, nevus, or papilloma. Marginal tissue involvement was seen predominantly in sebaceous carcinoma and SCC. It accounted for 53.6\% $(n=38)$ out of 67 cases of excised and exenterated specimens. Kafle et al. ${ }^{13}$ have also found marginal tissue involvement accounting for $67.9 \%$. According to the author, the increased frequency of marginal positivity is due to the larger size and extent of tumours at presentation, giving rise to difficulty in surgical removal with clear surrounding margins. We lack the detailed clinical information to explain the high frequency of margin positivity in the resected specimen of malignant tumours in the present study.

\section{CONCLUSIONS}

Benign eyelid lesions are predominant than malignant ones affecting usually younger adults with overall female preponderance. Basal cell carcinoma with the preferential location of the lower eyelid, and sebaceous carcinoma involving mainly the upper eyelid are common malignant tumours in the elderly population in our community. Moreover, high-grade sebaceous carcinoma with intraepithelial invasion is more common at initial presentation. Malignant lesions may masquerade as benign lesions; conversely, various benign lesions can clinically mimic different malignant tumours. Also, considering the increased chances of marginal tissue involvement in malignant lesions after excision with the resultant tendency of increased recurrence rate and metastasis, submission of all the eyelid lesions for histopathological examination seems relevant for further clinical management.

This study provides an overview of eyelid lesions in a diverse population. However, considering limitations in our study such as an interval of the study period of three years only and lack of detail clinical characteristics, a future large-scale multicentered research of a longer duration and collaboration with clinicians would be vital for a more accurate clinicopathological correlation providing a better understanding of the pathology of eyelid lesions.

\section{Acknowledgements}

We would like to sincerely thank the chairman of the National Research Laboratory, Kathmandu for providing us with the approval to perform the present study based on the data available in this laboratory. We would also like to appreciate and thank the technical personnel for their technical support.

\section{Conflict of interests: None}

\section{REFERENCES}

1. Font RL, Croxatto JS, Rao NA. Tumors of the eye and ocular adnexa AFIP atlas of tumor pathology, series 4, fascicle 5. Washinton DC: ARP press; 2006. Chapter 5, Tumours of the eyelids.155-21. Crossref

2. Pe'er J. Pathology of eyelid tumors. 2016;64:177-90. Crossref

3. Eberhart CG. Eye and ocular adnexa. In: Goldbum JR, McKenny JK, Lamps LW, Myers JL, editors. Rosai and Ackerman's surgical pathology. 11th ed. Philadelphia: Elsevier; 2017. 2112-17p.

4. Odashiro AN, Cummings TJ, Burnier MN. Eye and ocular adnexa. In: Mills SE, Grenson JK, Hornick JL, Longacre TA, Reuter VE, editors. Sternberg's diagnostic surgical pathology. 6th ed. Philadelphia: Wolter Kluwer Health; 2015. 1078- 81p.

5. Al-Faky YH. Epidemiology of benign eyelid lesions in patients presenting to a teaching hospital. Saudi J Ophthalmology. 2012; 26 : 211-6. $\underline{\text { Crossref }}$

6. Kersten RC, Chow DE, Kulwin DR, Gallon M.Accuracy of clinical diagnosis of cutaneous eyelid lesions. Ophthalmology. 1997; 104: 479-84. Crossref

7. Paul S, Vo DT, Silkiss RZ. Malignant and benign eyelid lesions in San Francisco: Study of a diverse urban population. Am J Clin Med. 2011; 8: 40-6. Website

8. Sushma TA., Geethamani V, Thejaswini MU et al. Epidemiology of neoplastic eyelid lesions in tertiary care hospital. In J Pathol Oncol. Jan-Mar, 2018; 5: 67-74. Crossref

9. Mohan BP, Letha V. Profile of eye lid lesions over a decade: a histopathological study from a tertiary care center in South India. Int J Adv Med. 2017; 4:1406-11. Crossref

10. Kumar R. Clinicopathologic study of malignant eyelid tumours. Clin Exp Optom 2010; 93: 4: 224-7. Crossref

11. Deprez M, Uffer S. Clinicopathological Features of Eyelid Skin Tumors. A retrospective study of 5504 cases and review of literature. Am J Dermatopathol. 2009; 31: 256-62. Crossref

12. Shields JA, Demirci H, Marr BP et al. Sebaceous carcinoma of the eyelids: personal experience with 60 cases. Ophthalmology. 2004;111:2151-7. $\underline{\text { Crossref }}$ 
13. Kafle PA, Hamal D, Sahu $\mathrm{S}$ et al. Clinicopathological analysis of malignant eyelid and adnexal tumours presenting to a tertiary eye hospital of eastern Nepal. Birat Journal of Health Sciences. 2019;:840-4. Crossref

14. Patterson JW. Weedon's Skin Pathology. 4th ed. Philadelphia, PA: Elsevier Churchill Livingstone. 2016.

15. Elder DE, Massi D, Scolyer RA, Willemze R, editors. WHO classification of skin tumours. 4th ed. Lyon (France): IARC; 2018.

16. McKee PH, Calonje E, Brenn T, Lazar A, editors. McKee's pathology of the skin with clinical correlation. 4th ed. China: Elsevier; 2012.

17. Government of Nepal, National Planning Commission Secretariat. Central Bureau of Statistics. National Population and Housing Census 2011 (NPHC 2011). National report. Kathmandu: Government of Nepal, National Planning Commission Secretariat, Central Bureau of Statistics; Nov 2012 volume 01. Website

18. 18. Cook Jr BE, Bartley GB. Epidemiologic characteristics and clinical course of patients with malignant eyelid tumors in an incidence cohort in Olmsted County, Minnesota. Ophthalmology. 1999;106:746-50. Crossref

19. Naik V, Mandrekar S, Amoncar S, Pinto RW. A Histopathological study of eyelid lesions at a tertiary care Hospital. Indian Journal of Clinical and Experimental Ophthalmology. 2019;5:348-51. Crossref

20. Damasceno JC, Isenberg J, Lopes LR et al. Largest case series of Latin American eyelid tumors over 13-Years from a single center in Sao Paulo, Brazil. Arq Bras Oftalmol. 2018;81:7-11. Crossref

21. Giri PM, Bharathi M, Shashidhar HB. Histomorphological spectrum of eyelid lesions-A 6 year retrospective study. Trop J Path Micro 2018:586-91. Crossref

22. Huang YY, Liang WY, Tsai CC et al. Comparison of the clinical characteristics and outcome of benign and malignant eyelid tumors: an analysis of 4521 eyelid tumors in a tertiary medical center. BioMed research international., vol. 2015, Article ID 453091, 5 pages, 2015. Crossref

23. Bastola P, Koirala S, Pokhrel G et al. A clinico-histopathological study of orbital and ocular lesions; a multicenter study. Journal of Chitwan Medical College. 2013;3:40-4. $\underline{\text { Crossref }}$

24. Lavaju P, Arya SK, Sinha A et al. Pattern of ocular tumors in the eastern region of Nepal. Nepalese Journal of Ophthalmology. 2009;1:9-12. Crossref

25. Ho M, Liu DT, Chong KK et al. Eyelid tumours and pseudotumours in Hong Kong: a ten-year experience Hong Kong Med J 2013; 19:150-5. Website

26. Chi MJ, Baek SH. Clinical analysis of benign eyelid and conjunctival tumors. Ophthalmologica 2006;220:43-51. $\underline{\text { Crossref }}$
27. Coroi MC, Rosca E, Mutia G et al. Eyelid tumors: histopathological and clinical study performed in County Hospital of Oradea between 2000-2007. Romanian Journal of Morphology and Embryology. 2010;51:111-5. Website

28. Patel M, Chavda BH, Shah Y et al. Study of incidence, occurrence, origin, and histological types of eyelid tumors at tertiary care hospital in Ahmedabad. Int J Sci Stud. 2019;6:16-19. Website

29. Yu SS, Zhao Y, Zhao $\mathrm{H}$ et al. A retrospective study of 2228 cases with eyelid tumors. International journal of ophthalmology.2018;11:1835. Crossref

30. Gündoğan FÇ, Yolcu Ü, Taş A et al. Eyelid tumors: clinical data from an eye center in Ankara, Turkey. Asian Pac J Cancer Prev, 16 , 426569. Crossref

31. Hsu HC, Lin HF. Eyelid tumors in children: a clinicopathologic study of a 10-year review in southern Taiwan. Ophthalmologica. 2004;218:274-7. $\underline{\text { Crossref }}$

32. Bagheri A, Tavakoli M, Kanaani A et al. Eyelid masses: a 10-year survey from a tertiary eye hospital in Tehran. Middle East African journal of ophthalmology. 20131;20:187-92. Crossref

33. Lin HY, Cheng CY, Hsu WM et al. Incidence of eyelid cancers in Taiwan: a 21-year review. Ophthalmology. 2006;113:2101-7. Crossref

34. Kaliki S, Bothra N, Bejjanki KM et al. Malignant eyelid tumors in India: a study of 536 Asian Indian patients. Ocular oncology and pathology. 2019;5:210-9. $\underline{\text { Crossref }}$

35. Domingo RE, Manganip LE, Castro RM. Tumors of the eye and ocular adnexa at the Philippine eye research institute: A 10-year review. Clin Ophthalmol. 2015;9:1239-47. Crossref

36. Lee SB, Saw SM, Eong KG et al. Incidence of eyelid cancers in Singapore from 1968 to 1995 . British journal of ophthalmology. 1999;83:595-7. Crossref

37. Anandani GM, Parikh SB, Shah NR. Histopathological study of eyelid lesions. Natl Lab Med. 2018; 7: 007-11. Crossref

38. Prabha DP, Padmavathi P, Ather M. Clinicopathological study of malignant eyelid tumours. Sch J App Med Sci. 2015;3:2165-8. $\underline{\text { Website }}$

39. Dasgupta T, Wilson LD, Yu JB. A retrospective review of 1349 cases of sebaceous carcinoma. Cancer.Jan 2009:158-65. Crossref

40. Shields JA, Saktanasate J, Lally SE et al. Sebaceous carcinoma of the ocular region: the 2014 Professor Winifred Mao lecture. The AsiaPacific Journal of Ophthalmology. 2015;4:221-7. Crossref 